\title{
The Effect of Relationship Marketing on Costumers' Loyalty in Iran Sanandaj City Banks
}

\author{
Mohammad Yaser Mazhari ${ }^{1}$, Abdolrazagh Madahi ${ }^{1} \&$ Inda Sukati ${ }^{1}$ \\ ${ }^{1}$ Faculty of Management and Human Resource Development, Universiti Technologi Malaysia (UTM), 81310 \\ Johor Bahru, Johor, Malaysia \\ Correspondence: Abdolrazagh Madahi, Faculty of Management and Human Resource Development, Universiti \\ Technologi Malaysia (UTM), 81310 Johor Bahru, Johor, Malaysia. Tel: 60-16-691-4688. E-mail: \\ khosoof_emaddeh@yahoo.com
}

Received: April 11, 2012

doi:10.5539/ijbm.v7n15p81
Accepted: June 11, 2012

Published: August 1, 2012

URL: http://dx.doi.org/10.5539/ijbm.v7n15p81

\begin{abstract}
Maintaining customers and keeping them loyal is considered vital for continuing business. In this study reported here examines the effect of four underpinnings of relationship marketing - trust, commitment, communication, and conflict handling - on customer loyalty in Iran. This research is a descriptive study done by survey method. The population in this study includes 400 costumers of private and state banks in Sanandaj of Iran. The instrument of data gathering was a questionnaire and the data were analyzed based on regression. Findings show that dependent variable is related to the independent variables meaningfully and positively.
\end{abstract}

Keywords: relationship marketing, customer's loyalty, state and private bank, Iran

\section{Introduction}

Nowadays companies which have higher function in different industries are moving forward to maintaining and keep customer loyal. Because most markets are in their grown up level, competition is increasing and expenses of new costumers are getting higher than ever (Kotler \& Armstrong, 1999). And the bank industry is not an exception, so the banks have to seek new managerial strategies in order to maintain their costumers' loyal (Ehigie, 2006). Todays, banks' managers have to understand the costumers' needs and desires more than ever and establish long-term business relationships with them in order to prevent their costumers to become interested in other banks. So any approach that can do the best in order to gain the goals of organization would be in center of attention. Relationship marketing as a new approach has been proved in research and practice that it is one of the most successful and practical methods (Anderson \& Narus, 1990). Proving the fact that relationship marketing has caused different advantages for organizations is the reason for large tendency to use it (Izquierdo \& Cillan, 2005). As an example, Richheld and Sasser found in their research that organizations can increase their interest up to 100 percent by keeping only 5 percent of their costumers (Richheld \& Sasser, 1990).

Finally organizations in Iran have to understand the importance of distinguishing their costumers' needs and move forward to make their costumers loyal to the organizations. Concerning the advent of private banks besides the state banks and the over increasing competition among private and state banks, relationship marketing could be considered as a solution to solve this predicament of banks. Using this approach, in addition to long-term relationship with costumers, it is possible to recognize the affairs and activities which are valuable in costumers' eyes and try to reinforce and strength them and attract new costumers and make them loyal to the organization. Thus organizations in addition to taking advantages of costumers' loyalty, they can improve their state in this competitive market. With the intention of gaining this goal, Iranian banks were also trying to propose solutions and programs to make and keep long-term relationship with their costumers and make them loyal finally.

As a consequence of significant advantages of relationship marketing, companies are moving toward choosing this approach as their strategy. Because in new conditions former methods don't have enough efficiency and they are less profitable. Most of the markets are grown up fully and face intense competition and large supplies far more than demands. In this condition, new costumers are hard to find so the urgent need to keep former costumers is strongly needed. In line with these changes, organizations have to be equipped and be ready to deal with their competitors. Therefore, relationship marketing is trying to keep previous costumers, so reduce the 
expenses of attracting new ones and increasing the interests of organizations. Relationship marketing includes some activities in order to develop long-term and advantageous relationships between costumers and organizations, with the intention of making mutual interest for both parties. In other way, preserving and strengthening the relationship is a one way pass that service organizations have to pass using defensive strategies and increase retaining their costumers.

The current research is a descriptive research which is done in a survey method and tries to study the effects of relationship marketing bases on costumers' loyalty in one private bank's branch and one state bank's branch in Iran-Sanandaj City. Here in this research, by relationship marketing the researcher means commitment, trust, communication and conflict management which these four elements are the independent variables of the research. Besides, costumers' loyalty is the dependent variable. And researcher by costumers' loyalty means is their possible reaction which can be in shape of increasing their deposit in the bank or reducing their deposit and their liquidity.

\section{Literature Review}

The relationship marketing was mentioned by Berry first in services issues and it is mentioned as the attracting, maintaining and improving relationship with costumers (Berry, 1983). Relationship marketing is about a company that is trying to do so as to distinguishing and offering better services to its valuable costumers. Relationship marketing is a continuous process in which organizations try to realize and prepare new values for their costumers in which bilateral and mutual interests are considered and these interests are going to be divided with the costumer in his period of being as a costumer. In relationship marketing swapping is one of the basic concepts. Marketing's core is exchanging the values in different relationships. The power of swapping partners in a trade is not equal, because they have different resources (Takala \& Uusitalo, 1996). Kotler (1999) described relationship marketing as developing, maintaining and improving strong relationships with costumers and other concerned (Kotler \& Armstrong, 1999).

According to Ndubisi (2007) four variables have been mentioned as relationship marketing items including trust, commitment, communication and conflict management. In his article these four variables have been concerned in order to show their effects on costumers' loyalty. Trust is one of the most important factors of relationship marketing. Dwyer and Schurr define trust as a party's belief in other party's statements (Dwyer \& Schurr, 1987). The second base for relationship marketing is commitment. Dwyer and Schurr define commitment as explicit or implicit commitment to continuity of relationship between the parties of an exchange (Dwyer \& Schurr, 1987). The third variable in relationship marketing is communication which means exchanging and sharing valuable and reliable information in time officially or unofficially between parties of a relationship (Sin \& Tse, 2005). And finally the fourth element of relationship marketing is conflict managing. Conflict is described as a level of disagreement between parties of exchange which it can be understood or clear. When conflict is increasing in a relationship, it results to reducing the trust and lack of interest in establishing long-term relations (Anderson \& Weitz, 1992). But conflict management is defined as a control for the overall disagreement level in working relationships. The seller's ability in order to maintain costumers is a vital element. We have to consider that total suppression of conflict can ruin the relationship and the parties could separate before being engaged in a long-term and continuous relationship (Dwyer \& Schurr, 1987).

Furthermore, costumer's loyalty is a concept which has been used widely in costumers' behavior for many years. As an example, Rick and Basso (1994) considered costumers' loyalty as power of making relationship between wage attitude about existence (brand, services, store, seller and etc) and the repetition of buying. Researchers think of the over increasing attention of banks toward their loyal costumers for several reasons. One of its most important can be found in profitability state of these customers for the banks. Hallowell in a research about 12,000 banks and studied relationship between costumers' satisfaction and loyalty and this research shows a positive relationship between costumers and profitability (Hallowell, 1996). Reinartz and Kumar (2002) found the same results in their research that a large percentage of costumers who have had long term relationship with the banks, they were more profitable for organization than other costumers (Reinartz \& Kumar, 2002).

Considering the fact that available services in trade banks are rather the same and having specific and distinct services is difficult for most banks comparing to their competitors, so a large number of world's banks are going to have a tendency to use relationship marketing (So \& Speece, 2000). Adamson and Chan (2003) found in their research that successful banks comparing not successful banks have done more efforts in order to fulfill relationship marketing and founding long-term relationships with their costumers (Adamson \& Chan, 2003). But in most executives and researchers point of view, the most important result of using relationship marketing in 
banks just like other service providers is making their costumers loyal and this is the result which banks' marketing experts are looking for (Gilbert \& Choi, 2003).

\section{Research Methodology}

This research includes 5 personal questions and 23 attitude questions in order to study the effect of relationship marketing bases on costumers' loyalty and comparing state and private banks in Kurdistan province of Iran. This questionnaire has been distributed among 425 people of banks' costumers in Sanandaj city which 400 persons have answered the questions completely. Since the population of the research is very broad, so an earlier study had been done before the main research was done. The primary research included 30 questionnaires in each of the private and state banks. The questionnaire was a researcher made one and it included five questions about trust, six questions about commitment, five questions about communications, five questions about conflict management, four questions about customers' loyalty and finally five personal questions has been asked from customers. The measuring scale of items was Likert Scale analyses which number 1 stands for strongly disagree to number 5 stands for strongly agree and number 3 stands for no opinion.

\subsection{Research Framework}

This model is taken from Ndubisi's model which is presented in the Figure 1. This model includes four independent variables including trust, commitment, communication and conflict management and the dependent variable is customers' loyalty.

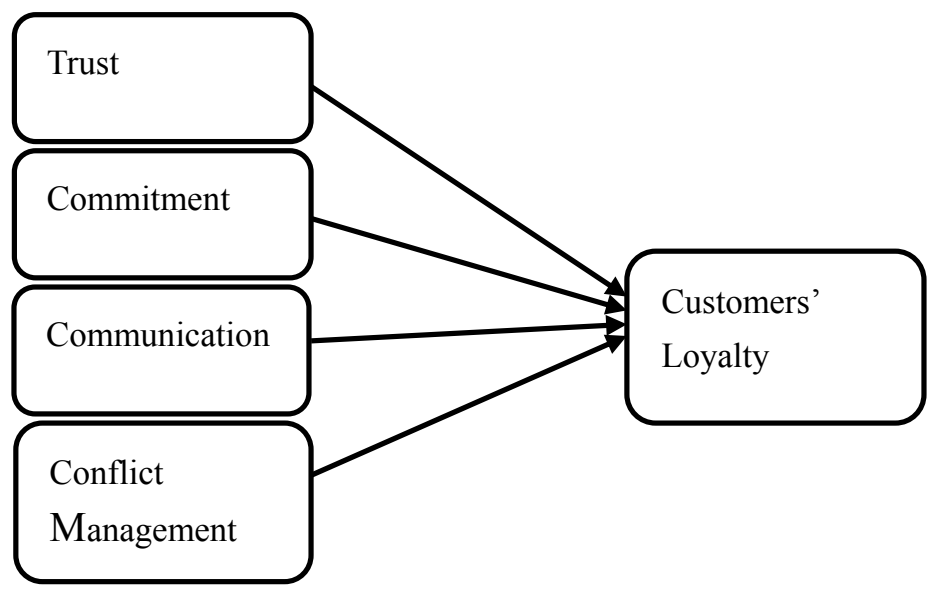

Figure 1. Research framework

\subsection{Hypotheses Development}

The current research is a descriptive research which is done in a survey method and tries to study the effects of relationship marketing bases on costumers' loyalty in one private bank's branch and one state bank's branch in Sanandaj of Iran by means of regression method. Pearson correlation gained by statistical analyzing of acquired data shows the existence or lack of existence of relationship between independent variables and dependent variables. The model which has been used in this research is taken from Ndubisi's model. This model includes four independent variables including trust, commitment, communication and conflict management and the dependent variable is customers' loyalty. This research's hypotheses have been arranged as follows:

1) Bank's trust is related to customers' loyalty.

2) Bank's commitment to provide customers with satisfaction is related to customers' loyalty.

3) The quality of banks' communication with their customers is related to their customers' loyalty.

4) Bank's ability in conflict management is related to customers' loyalty.

\subsection{Respondent Profile}

210 people who have been studied are from a state bank and 190 people (47.5\%) were from a private bank as it is clear the most frequency is about state bank with $52.5 \%$ of our population.

According to table (1), 100 people who have been studied were women and 300 people were men which the frequency is for men about $75 \%$ of our population. 30 people of the population were in their under thirties, 110 people were between thirty to thirty five, 150 people were between thirty five and forty and 30 people were 
between forty five to sixty which as it is clear the frequency is in range of thirty five to forty which was about $37.5 \%$ of our population. Furthermore, 40 people of the population were under diploma in their educational level, 180 people had associate diploma, 170 people had bachelor degree and 10 people had master degree or higher. As it shows the frequency is in associate degrees about $45 \%$ of the population.

Table 1. Sample of demographic profile

\begin{tabular}{llll}
\hline Demographic Factors & & Frequency & Percentage \\
\hline Age & 30 & 110 & 27.5 \\
& $30-35$ & 110 & 27.5 \\
& $35-40$ & 150 & 37.5 \\
& $45-60$ & 30 & 7.5 \\
Gender & Male & 300 & 75 \\
\multirow{3}{*}{ Education } & Female & 100 & 25 \\
& Less than a high school diploma & 40 & 10 \\
& Associate degree & 180 & 45 \\
& Bachelor's degree & 170 & 42.5 \\
& Master's degree and higher & 10 & 2.5 \\
\hline
\end{tabular}

\section{Results}

According to hypothesis 1 (H1) Bank's trust is related to customers' loyalty. In order to study the relationship between trust, commitment, quality of communication and conflict management one-way ANOVA has been used and according to the results of table (2) it is possible to say that because the calculated correlation is 0.731 and the meaningful level is 0.000 which is lower than calculated Cronbach's Alpha which is about 0.05 . So it is possible to state that there is a meaningful relationship between bank's trust and customers' loyalty level. In other words, when the bank's trust increases the loyalty level of customers will be increased, too.

According to hypothesis 2 (H2) bank's commitment to provide customers with satisfaction is related meaningfully to customers' loyalty. According to the results of table (2) it is possible to say that because the calculated correlation is 0.708 and meaningful level is 0.02 lower than Cronbach's Alpha which was 0.05. It means that bank's commitment to provide customers with satisfaction is related meaningfully to customers' loyalty. So, as the bank's commitment to provide customers with satisfaction is rising, customers' loyalty will be increasing.

According to hypothesis $3(\mathrm{H} 3)$, the quality of banks' communication with their customers is related meaningfully to their customers' loyalty; Calculated correlation is 0.617 and the meaningful level is 0.000 which is lower than the Cronbach's Alpha (0.05) so it is possible to say that there is a meaningful relationship between the quality of banks' communication with their customers and increases of customers' loyalty. It means if the quality of banks' communication with their customers' increases, their customers' loyalty will increase, too.

According to hypothesis 4 (H4), there is a meaningful relationship between bank's ability in conflict management and customers' loyalty. Calculated correlation is 0.814 and the meaningful level is 0.000 which is lower than the Cronbach's Alpha (0.05), so it is possible to say that there is a meaningful relationship between the bank's ability in conflict management and customers' loyalty, therefore if bank's ability in conflict management increases, customers' loyalty will increase. Among these four independent variables, conflict handling has the highest correlation value of 0.814 , followed by trust $(\mathrm{r}=0.731)$, commitment $(\mathrm{r}=0.708)$ and communication $(r=0.617)$. 
Table 2. A regression analysis is related to the relationship of trust, commitment, communication quality and conflict management by bank and customers' loyalty

\begin{tabular}{lll}
\hline Effect & Pearson Correlation & Sig \\
\hline Trust & 0.731 & 0.000 \\
Commitment & 0.708 & 0.02 \\
Communication & 0.617 & 0.000 \\
Conflict Management & 0.814 & 0.000 \\
\hline
\end{tabular}

Furthermore in this research which includes 23 questions about the effect of relationship marketing on customers' loyalty in two branches of state and private banks of Kurdistan of Iran in which for every question the Cronbach's Alpha has been calculated and it was 0.857 . So the research has enough reliability and validity in its own case.

\section{Discussion on Findings}

Based on findings which were acquired by analyzing the results of the first question of the hypotheses we can come to this conclusion that there is a meaningful relationship between trust-building by banks and their customers' loyalty. In other words, in any level the confidence-building is growing, the customers' loyalty is increasing in the same level. There are limitations for this hypothesis. For example some other branches which are new founded are not familiar with their new customers and they don't trust to their new customers, or sometimes obtaining expensive collaterals can cause a kind of distrusting between customers and the bank and it may cause a disturbing feeling in customers which they are not trusted by the bank. Economical problems and currency fluctuations in Iran have small effects on trust-building. There are some suggestions in order to solve these problems including increasing the rate of interest for deposits which has a great effect on customers' desire and zest, or trying to obtain less expensive collaterals from customers, and finally trying to behave more sincerely and friendly which can lead to confidence-building.

And also by studying the results of the second hypothesis we can assume that there is a meaningful relation between bank's commitments to provide customers with satisfaction and the costumers' loyalty. It means when banks try to show their commitment in case of providing costumers' satisfaction their costumers would be more loyal to them than ever. But there are some limitations in this point because in some cases banks are neglecting their responsibilities and it leads to less confidence from costumers' party and their willing to invest their deposit in that bank will decrease mainly. Nevertheless there are some ways out for these situations. For example informing costumers about the content of recognizances arranged between parties, paying more attention to costumers' ideas and suggestion in case of adjusting the recognizances, and finally being committed to their recognizances despite the Economical problems and currency fluctuations.

By considering the results of the third hypothesis we can adopt that there is a meaningful relation between quality of communications of bank and costumers loyalty. Subsequently, whenever the quality of banks communication with its own costumers is better the level of costumers' loyalty is higher. There are some limitations for this case counting lack of time for the banks which leads to lack of enough communications with their costumers. Nowadays, banks use internet and SMS to communicate with their customers which because of some telecommunication problem there are often delays in these kinds of transferring information. But there are some solutions for these problems including a program to increase direct and indirect communications which are really effective in attracting customers to the banks. They can also hold meetings and conferences which are useful in gathering customers and improving their communications.

By considering the results of the last hypothesis it is true to say that there is a meaningful relation between bank's ability in handling the conflicts between bank and customers and the level of customers' loyalty. Limitation which can be mentioned for this hypothesis is that the degrees and records of managers, which can affect customers' point of view, are not in high levels. So it could be suggested to solve this problem, banks should use the best of their managers; improve their behavioral communications to a higher level for managers and clerks. And finally bans can provide long-term loans for people in order to show them their commitment and loyalty. 


\section{Limitation and Future Research}

In this research a state bank and a private bank has been studied, so it is recommended that in order to increase the generalizability the number of state and private banks which are going to be studied increases and paying more attention to their changes among their activities.

In addition, in this study, we have not measured and analysed the effect of some crucial and significant factors such as culture, income, geography, education and demography on customers' loyalty, so future investigate could analyse the influence of these factors on customers' loyalty. Furthermore, data analysis was limited to some bank customers in Sanandaj city (Kurdistan province) only. Future research could incorporate data from customer groups from different regions and different age groups to obtain better result and increase the validity of research.

\section{Conclusion}

This article is studying the effects of bases of relationship marketing on customers' loyalty in a branch of a state and a branch of a private bank in Sanandaj city of Kurdistan of Iran. In this article, in order to study the relationship between relationship marketing and customers' loyalty the Ndubisi's model has been used (Ndubisi, 2007). According to this model there are four independent variables including trust, commitment, communication and conflict management and the dependent variable is customers' loyalty in one branch of each state and private banks which have been analyzed by means of regression method. 400 people attended in this research in which 30 questionnaires have been distributed in each branch. The results show that all of the four variables have positive and meaningful relationship with customers' loyalty and they have positive effects on dependent variable.

\section{Acknowledgement}

I would like to express my gratitude to Universiti Technologi Malaysia (UTM), which provided me the opportunity to do my $\mathrm{PhD}$ and broaden my academic and business horizons.

\section{References}

Adamson, Chan, K. M., \& Hand, D. (2003). Relationship marketing: customer commitment and trust as strategy for the smaller Hong Kong corporate banking sector $\mathrm{n}$. International journal of bank marketing, 21(6/7), 347-358. http://dx.doi.org/10.1108/02652320310498492

Anderson, E., \& Weitz, B. (1992). The use of pledges to build and sustain commitment in distribution channels. Journal of Marketing Research, 19(1), 18-34. http://dx.doi.org/10.2307/3172490

Anderson, J. C., \& Narus, J. A. (1990). A model of distributor film and working partnerships. Journal of Marketing, 54(1), 42-58. http://dx.doi.org/10.2307/1252172

Berry, L. L. (1983). Emerging perspective on services marketing. American marketing Association.

Pressey, A. D., \& Mathews, B. (2000). Barriers to Relationship Marketing in Marketing. Journal of Service Consumer Retailing, 14(3), 272-286.

Chiu, H. C., Hsieh, Y. C., LI, Y. C., \& Lee, M. (2005). Relationship marketing and consumer switching behaviour. Journal of Business Research, 58, 1681-1689. http://dx.doi.org/10.1016/j.jbusres.2004.11.005

Jones, E., \& Richards (2008). Customer Relationship Management. Industrial marketing management, 37 , 120-130. http://dx.doi.org/10.1016/j.indmarman.2006.08.005

Dwyer, F. R., Schurr, P. H., \& Oh, S. (1987). Developing Buyer Seller Relationships. Journal of Marketing, 51, 11-27. http://dx.doi.org/10.2307/1251126

Ehigie, B. O. (2006). Correlates of customer loyalty to their bank: a case study in Nigeria. International Journal of Bank Marketing, 24(7), 494-508. http://dx.doi.org/10.1108/02652320610712102

Gilbert, D. C., \& Choi, K. C. (2003). Relationship marketing practice in relation to different bank ownerships: a study of banks in Hong Kong. The International Journal of Bank Marketing, 21(2/3), 137-46. http://dx.doi.org/10.1108/02652320310469511

Gronroos, C. (1994). From marketing mix to relationship marketing: Towards a paradigm shift in marketing. Management Decision, 32(2), 4-20. http://dx.doi.org/10.1108/00251749410054774

Hallowell, R. (1996). The relationships of customer satisfaction, customer loyalty, and profitability: an empirical study. International Journal of Service Industry Management, 7(4), 27-42. http://dx.doi.org/10.1108/09564239610129931 
Lzquierdo, C. C., \& Cillan, J. G. (2005). The impact of customer relationship marketing on the film performance. Journal of service Marketing, 19(4), 234-244. http://dx.doi.org/10.1108/08876040510605262

Kotler, P. (2003). Marketing Insights from A to Z: 80 Concepts Every Manager Needs to Know.

Kotler, P., \& Armstrong, G. (1999). Principles of marketing (8th edition). Prentice Hall, Upper Saddle River, New Jersey .

Morgan, R. M., \& Hunt, S. D. (1994). The commitment - trust theory of relationship marketing. Journal of Marketing, 58 (3), 20-38. http://dx.doi.org/10.2307/1252308

Ndubisi, O. N., \& Wah, C. K. (2005). Factorial and discriminant analyses of the underpinning of relationship marketing. International Journal of Bank Marketing, 23(7), 542-557. http://dx.doi.org/10.1108/02652320510629908

Ndubisi, O. N. (2007). Relationship marketing and customer loyalty. Marketing Intelligence \& Planning, 25(1), 98-106. http://dx.doi.org/10.1108/02634500710722425

Oliver, R. L. (1999). Whence Consumer Loyalty. Journal of marketing, 63, 33-44.

Rashid, T. (2003). Relationship marketing case studies of personal experience of eating out. British food journal, 105(10), 742-750. http://dx.doi.org/10.1108/00070700310506281

Reichheld, F., \& Sasseer, W. (1990). Zero defections: quality comes to services. Harvard Business Review, 105-111.

Reinartz, W. J., \& Kumar, V. (2002). The mismanagement of customer loyalty. Harvard Business Review, 80(7), 4-12.

Samiee, S., \& Walters, P. G. P. (2003). Relationship Marketing in an International Context. International Business Review, 12, 193-214. http://dx.doi.org/10.1016/S0969-5931(02)00096-3

Sin, L. Y. M., Tse A. C. B., Yau, O. H. M., Lee, J. S. Y., \& Chow, R. (2002). The effect of relationship marketing orientation on business performance in a service - oriented economy. Journal of service marketing, 16(7), 656-676. http://dx.doi.org/10.1108/08876040210447360

Sin, L. Y. M., Tse A. C. B., Yau, O. H. M., Lee, J. S. Y., \& Chow, R. (2005). Relationship marketing orientation: scale development and cross cultural validation. Journal of Business Research, 58, 185-194. http://dx.doi.org/10.1016/S0148-2963(02)00493-9

So, S. L. M., \& Speece, M. W. (2000). Perceptions of relationship marketing among account managers of commercial banks in a Chinese environment. International Journal of Bank Marketing, 18(7), 315-327. http://dx.doi.org/10.1108/02652320010359534

Thurau, T. H., Gwinner, K. P., \& Gremler, D. D. (2002). Understanding Relationship Marketing Outcomes an Integration of Relational Benefits and Relationship Quality. Journal of Service Research, 4(3), 230-247. http://dx.doi.org/10.1177/1094670502004003006

Zins, A. H. (2001). Relative attitudes and commitment in customer loyalty models. International Journal of Service Industry Management, 12(3), 269-294. http://dx.doi.org/10.1108/EUM0000000005521 